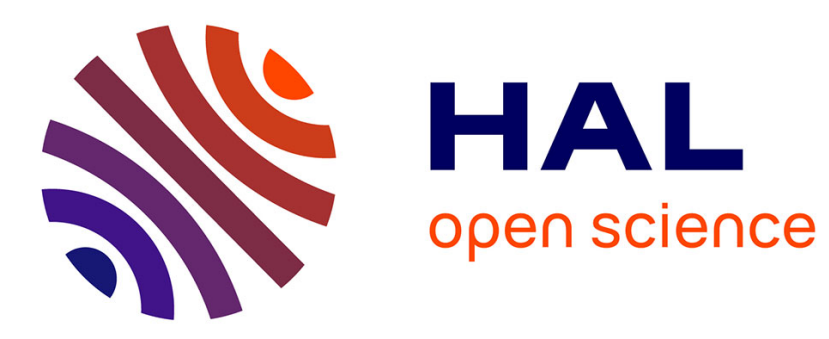

\title{
Innovation in Brazilian landfills: A ServPPIN perspective
}

Silvia Cruz, Sônia Paulino, Faïz Gallouj

\section{To cite this version:}

Silvia Cruz, Sônia Paulino, Faïz Gallouj. Innovation in Brazilian landfills: A ServPPIN perspective. XXIV. International RESER Conference: Services and new societal challenges: innovation for sustainable growth and welfare, RESER, Sep 2014, Helsinki, Finland. halshs-01134031

\section{HAL Id: halshs-01134031 https://shs.hal.science/halshs-01134031}

Submitted on 21 Mar 2015

HAL is a multi-disciplinary open access archive for the deposit and dissemination of scientific research documents, whether they are published or not. The documents may come from teaching and research institutions in France or abroad, or from public or private research centers.
L'archive ouverte pluridisciplinaire HAL, est destinée au dépôt et à la diffusion de documents scientifiques de niveau recherche, publiés ou non, émanant des établissements d'enseignement et de recherche français ou étrangers, des laboratoires publics ou privés. 


\title{
XXIV. International RESER Conference: Services and new societal challenges: innovation for sustainable growth and welfare
}

\author{
Helsinki, 11-13 September 2014
}

\section{Innovation in Brazilian landfills: A ServPPIN perspective}

\author{
Silvia Cruz (corresponding author) ${ }^{1}$ \\ Sônia Paulino* \\ Faïz Gallouj ${ }^{* * * *}$
}

\begin{abstract}
This paper is devoted to the discussion of public services innovation in the Brazilian municipal solid waste sector, with emphasis on multi-agent participation within Clean Development Mechanisms (CDM) projects. The empirical context is based on six landfill CDM projects located in the São Paulo Metropolitan Area, Brazil. $\mathrm{CDM}$ projects have a dual purpose: reducing greenhouse gas (GHG) emissions and promoting local sustainable development in host countries - through the promotion of local co-benefits. The discussion is based on the analytical model provided by the ServPPIN concept (public-private innovation networks in services). It focuses on the characterization of the landfills selected and on the identification of the stakeholders involved within these landfills, pointing out the participation gaps. The results indicate that the participation of associations and cooperatives surrounding landfills is still marginal. Pulling this theoretical (ServPPIN) and empirical research (landfill CDM project) together, one can identify the main factors affecting the establishment of basic conditions for service innovation: a) interactions and the building of social relations aimed at innovation among various stakeholders; b) the development of competences on several fronts; especially relational and organizational; c) the role of the public sector (coordination role) in supporting the development of successful public-private innovation networks in services.
\end{abstract}

Keywords: ServPPIN; public service innovation; clean development mechanism; solid waste sector.

\section{Introduction}

This paper is devoted to the discussion of public services innovation in the Brazilian municipal solid waste sector, with emphasis on multi-agent participation within Clean Development Mechanisms (CDM) projects. The empirical context is based on six landfill CDM projects located in the São Paulo Metropolitan Area, Brazil. It comprises 39 municipalities, and approximately 20 million inhabitants, generating around 16 thousand tonnes of solid waste per day (Cetesb, 2013).

The discussion is based on the analytical model provided by the ServPPIN concept (public-private innovation networks in services) (Gallouj and Weinstein, 1997; Bučar et al., 2013; Djellal and Gallouj, 2013; Gallouj et al., 2013; Labarthe et al., 2013). Beyond the relational aspect (interfaces and feedbacks) among various public and

\footnotetext{
${ }^{1}$ University of Campinas (Unicamp), Department of Scientific Policy and Technology, R. João Pandiá Calógeras, 51, Barão Geraldo, 13083870 - Campinas, SP - Brasil, silviacruz@ige.unicamp.br. Acknowledgements: This work was supported by Grant 2011/00081-5, São Paulo Research Foundation (FAPESP); CAPES Foundation/Ministry of Education of Brazil; and Centre Lillois d'Études et de Recherches Sociologiques et Économiques (CLERSÉ).

** University of São Paulo, School of Arts, Sciences and Humanities (EACH), Av. Arlindo Bettio, 1000; São Paulo-SP; CEP 03828-000, Brazil, sonia.paulino@usp.br

*** University of science and technology (Lille1),Centre Lillois d'Études et de Recherches Économiques et Sociologiques, University of science and technology (Lille 1) Faculty of economics and sociology Bâtiment SH2 59655 Villeneuve d'Ascq, France, faiz.gallouj@univ-lille1.fr
} 
private actors, the ServPPIN concept emphasizes third sector organizations' (associations, NGOs etc.) participation in different ways. It highlights the important institutional and regulatory role of the public sector, decisive in the success and sustainability of the network; and it points out the importance of non-technological innovation.

CDMs encompass activities aimed at reducing greenhouse gas (GHG) emissions by establishing projects across a wide range of sectors, including landfill sites. In line with article 12 of the Kyoto Protocol, these projects must also contribute to promoting sustainable development in their host countries, through the establishment of local social and environmental co-benefits. Although the CDM projects have a dual purpose (reducing GHG emissions and promoting local sustainable development in host countries - through the promotion of local co-benefits), the United Nations Framework Convention on Climate Change (UNFCCC) does not establish indicators to evaluate social and environmental co-benefits.

According to the Marrakech Accords (Decision 17/CP. 7) the responsibility for determining whether a CDM project activity contributes to sustainable development is defined by the host country and resides with its Designated National Authority (DNA) (UNFCCC, 2001). The Letter of Approval (LoA), a document which confirms that the project contributes to the sustainable development of a particular country, is issued by the DNA and is exclusively based on the objectives of local contributions to sustainable development, as set out by the proponents of the project.

In Brazil, the specifications of a project in order to promote local sustainable development are based on information from Annex III of Resolution n.1 of the Inter-Ministerial Commission on Global Climate Change ${ }^{2}$. This establishes both the benefits to the local area and how project activities contribute to each of the following aspects: environmental sustainability; improvement in working conditions and net job creation; income distribution; training and technological development; and finally, regional integration and working in conjunction with other sectors (Brazil, 2003). However, analyzes performed on the promotion of local development, based on the CDM projects in the solid waste sector, indicate that most of the projects do not contribute significantly to the achievement of local sustainability (Sutter and Parreño, 2007; Siebel et al., 2013). In this direction, the importance of civil society's effective participation throughout the approval process of a CDM project is noticeable.

CDM projects are not implemented with the explicit goal of promoting service innovation; however, these projects can create leverage and open new possibilities to improve services related to urban solid waste, converging with the National Policy on Solid Waste (Brazilian law $\left.n^{\circ} 12,305 / 2010\right)$ requirements and social and environmental co-benefits generation from carbon market projects.

In this manner, there is need for the development of activities which focus on the steps for generation and treatment of solid waste, preceding the final disposal of waste, searching for alternatives to reduce the generation of waste, encouraging actions for reuse, recycling, and treatment.

Besides these, landfill CDM projects can improve management practice during the operation of landfills (air pollution, groundwater contamination, biogas management, visual, freight vehicle access arrangements, etc) as well as improve on activities carried out after landfill closure, in order to fulfil with the closure plan of the landfill area (maintenance of the vegetation, landfill cover system etc.).

Activities carried out in the projects developed in landfills involve various agents: concession-holders responsible for managing the landfill and capturing landfill gas (LFG); municipal departments; and representatives of associations from the communities surrounding the landfills. The importance of civil society's effective participation throughout the approval process of a CDM project cannot be overstated. Indeed, project proponents should send letters of invitation to all project stakeholders. The following agents should be considered in the case of Brazil: local authorities and chamber of deputies for all municipalities involved; municipal and state environmental departments; NGOs and social movement forums; community associations both directly and indirectly involved in project activities; and State and Federal Public Prosecution Offices.

In this context, this paper intends to analyze how the promotion of local co-benefits is linked to the promotion of innovation in urban solid waste services, emphasizing the participation of civil society, highlighted in the Kyoto Protocol and in the ServPPIN concept. The paper is structured into four sections. Following the introduction, section 2 discusses the public services through the ServPPIN concept, focusing on the multi-faceted and heterogeneous nature of the public sector and on the role of the civil society in innovation in public services. Section 3 is devoted to the presentation of empirical cases, focusing on the characterization of the landfills selected and on the identification of the stakeholder involved with these landfills, pointing out participation gaps, taking into account the following criteria: consultation, benefits, and interaction/interface. Our conclusions are set out in section 4.

\footnotetext{
${ }^{2}$ Inter-Ministerial Commission on Global Climate Change is the Designated National Authority (DNA) in Brazil.
} 


\section{ServPPIN concept and the role of the civil society in innovation in public services}

The purpose of this section is to present: 1) specific characteristics of public sector and public service innovation; 2) the concept of public-private innovation networks (ServPPIN), highlighting the importance of multiple links and feedbacks between the public and private sectors, and also with service users and; 3 ) the role that third sector organizations/end users (citizens) have to play in the ServPPIN context.

\section{Innovation in Public Services}

There is an increasing scientific literature on innovation in the public sector. However, the literature generally neglects or underestimates the role of the public sector in the innovation process (Djellal et al, 2013, Windrum and García-Goñi, 2008; Brandão and Bruno-Faria, 2013; Osborne and Brown, 2013).

The public sector is often portrayed as a facilitator of innovation activities, merely drafting the legal framework, among other actions which do not include a leading role in the innovation process (Gallouj and Weinstein, 1997; Mulgan and Albury, 2003; Hartley, 2005; Halvorsen et al. 2005; Koch and Hauknes, 2005; Windrum and García-Goñi, 2008; Potts and Kastelle, 2010; Fuglsang, 2010; Sundbo, 2013; Djellal and Gallouj, 2013; Djellal et al. 2013; Osborne and Brown, 2013).

Although the idea has long been prevalent that public services are produced, predominantly, by the public sector, more recently there is improved clarity that public service provision generally involves a more complex and broad range of actors and institutions: public services can be provided by public actors, private actors, or both (Di Meglio, 2013). In this manner, systematic efforts will be required to foster innovation in the public sector (Bloch and Bugge, 2013), and, therefore, in public services.

Djellal and Gallouj (2012) highlight the importance of public services according to the output produced by these services, which can be called social or civic outputs. According to the authors "These 'outputs' contribute to social cohesion, solidarity and collective and civic identity" (Djellal and Gallouj, 2012, p. 11).

Another aspect of public service provision is the difficulty of identifying and demarcating activities that should be attributed to the public sector as opposed to the private sector, as many services and activities in the public sector are integrated with the activities of the private sector and vice versa (Bugge et al, 2010; Potts and Kastelle, 2010). This aspect is observed also for services related to municipal solid waste that generally is carried out through concessions to the private sector.

According to Bugge et al (2010) and Bloch and Bugge (2013) the multi-faceted and heterogeneous nature of the public sector is a result of the multiple interfaces which characterize public organizations: 1) the interface with the private sector; 2) the interface between the public sector and citizens; and 3) the internal interfaces within the public sector (between government levels and between different areas of activity). These various interfaces, illustrate public sector heterogeneity, and also the permeability between organizations (private, public, and third sector) (Gallouj et al, 2013).

Having outlined the characteristics of multiple interfaces and heterogeneity of the public sector, the publicprivate innovation networks in services (ServPPIN) concept can be useful in understanding the logic of public service innovation.

\section{Public-Private Innovation Networks in Services (ServPPIN)}

One of the factors encouraging interest in examining Public-Private Innovation Networks is the growing recognition of the important role played by public sector organisations in the innovation process. Public administrations are thus no longer restricted to playing a supporting role in the innovation process. They may be active participants in that process, particularly insofar as their own activity is concerned.

Just like public-private partnerships (PPPs), ServPPINs are networks of collaborative partnerships between public and private organizations. However they are more comprehensive, open and flexible than traditional PPPs, which entail relations between actors that are more rigid, with predefined functions, rules and formal procedures (particularly contracts) that can bureaucratize the process, and limit the potential for innovation.

The high number, and diversity, of participants in a ServPPIN can lead to a complex and intensive process of interaction in which a large amount of heterogeneous information and knowledge (tacit and non-tacit) are likely to be exchanged, since plenty of channels are opened for interaction. In other words, ServPPIN can be thought of as a multi-agent service relationship system (Djellal and Gallouj, 2013).

The innovation network ${ }^{3}$ concept is biased towards manufacturing and technology. This concept, in the traditional sense, suffers from a certain number of shortcomings; namely: a technology bias (with largely

\footnotetext{
${ }^{3}$ Innovation networks and systems have been the subject of an extensive literature in economics, sociology and management (Callon, 1992; Edquist, 1997; Latour, 1999; Lundvall, 1992; Nelson, 1993 among others).
} 
predominance of tangible technological innovation), a manufacturing bias (linked to the previous one), and a market bias (the private sector is central to innovation dynamics). This means in short that innovation networks are mainly focused on technological innovation produced by the collaboration of private actors in the manufacturing sector.

The ServPPIN concept provides a way of overcoming these various biases (Djellal and Gallouj 2013; Gallouj et al., 2013; Labarthe et al. 2013, Windrum, 2013). It goes beyond the technologist view of innovation ${ }^{4}$. Its perspective is broader, incorporating non-technological types of innovation such as: organizational, ad hoc (defined by Gallouj and Weinstein [1997] as the interactive solution to the specific problems of particular clients), social, and bricolage innovation (defined as innovation through non-programmed activities, trial-anderror processes and adaptation to random events - [Fuglsang, 2010]).

Through the ServPPIN concept, Di Meglio (2013), Gallouj et al (2013) and Langergaard and Scheuer (2009), emphasizes the importance of multiple links and feedbacks (interfaces) between public and private sector, and also with users - in our case, representatives of associations from the communities' surrounding landfills - and policy makers for service innovation. As pointed out by Djellal and Gallouj (2013):

ServPPINs are multi-agent service relationship systems. The actors involved in interaction have to deal with the illdefined nature of their respective products, their non-stockability, a diversity of systems of interaction, the multiplicity of possibly competing value systems and the fact that their products are located in different spatial and temporal scales. ServPPINs introduce the traditional research questions of service economics into network-based analyses of innovation. (Djellal and Gallouj, 2013, p. 30 highlighted by the authors).

According to Bučar et al. (2013), ServPPINs can be understood as a place for social interaction and the construction of social relations aimed at innovation. Nevertheless, of all case studies provided by the ServPPIN research project ${ }^{5}$, several were not explicitly oriented towards the innovation target. For example, in some hospital case studies the main objective was to reduce costs in the use of technologies (Farias and Almeida, 2014; Schartinger, 2013; Windrum, 2013).

Similarly the CDM landfill projects we examined were implemented in order to reduce GHG emissions, rather than having the explicit goal of promoting service innovation. In fact, the technology and innovation outcomes appear to be additional results of the local co-benefits generation. Interesting changes and innovations are likely to arise out of such networks - which can then be retrospectively labelled 'innovation networks'. Taking into account non-technological, incremental and non-programmed innovations (ad hoc, bricolage, rapid application etc.) it is also possible to consider even those networks which are not explicitly (or immediately) oriented towards innovation to be ServPPINs.

The ServPPIN contributes to opening up the traditional innovation network concept to new actors: all market services, as well as third-sector organisations (NGOs, associations etc.). It extends potential forms of participation for certain actors, for example, the involvement of civil society in the decision-making and consultation processes. This is particularly the case with regards to the role civil society plays in the ServPPIN context - helping to translate social preferences which are not merely reflected by market prices (Fuglsang, 2013).

\section{Public Service Users and Their Involvement in Service Innovation}

The innovation process involves several players who contribute in different ways in the development of service innovations. In this sense, the involvement of customers/service users as 'partners' in the process of service innovation development is highlighted, which can be achieved through dialogue with service users, joint experimentation, panels and other communication tools (Hertog et al; 2010). It is noteworthy in recent years that the participatory governance mechanisms have been widely promoted in developing countries (Speer, 2012). These mechanisms seek to involve citizens in decision-making regarding the allocation of public resources among communities, shaping public policy, as well as involvement in the monitoring and evaluation of government expenditure.

According to Speer (2012), one of the key reasons cited for participatory governance mechanism implementation is related to the improvement of public services. Given that when citizens are empowered and democracy strengthened there is a tendency to an increase in local government responsiveness and accountability. This process tends to improve the efficiency and sustainability of public service delivery, since it

\footnotetext{
${ }^{4}$ The technology issue is taken into account in the designs of the carbon market projects and regarding the promotion of social and environmental local co-benefits, in the cases studied, all Project Design Documents (PDD) and Validation Reports indicate the development and diffusion of technologies through the project's implementation, highlighting the following aspects: training, technology development and transfer.

${ }^{5}$ ServPPIN is an EU-funded research project which focuses on the role of public and private services on growth and welfare and the particular role of public-private innovation networks. For more information: http://www.servppin.com/. The main results of the project are also published in Gallouj, Rubalcaba and Windrum (2013).
} 
might have the ability to match public services to user preference.

Participatory governance mechanisms can improve information flows in two ways: from citizens to governments about citizen preferences/demands; and from governments to citizens about government decisions and actions, as well as about service provision outcomes.

Lehtonen and Tuominen (2013) emphasize the collective preferences of citizenship, with a broader vision of the citizen, not only as a public service receptor, but also active in the production, control and planning of these activities. The authors note that active dialogue is required to negotiate and mediate under different citizen preferences. In this context, the relevance of user integration in the service innovation process it is brought to attention.

However, ServPPIN research Project results (Gallouj et al, 2013) show the limitation of the third sector organizations' participation and that the involvement of service end users (citizens) is marginal. Thus, especially regarding to the role that civil society has to play in ServPPIN - assisting in the translation of social preferences - there is a need to empower public users in order to foster successful cooperation.

Schilling (2011) points out that improvements in cooperation among the agents is coupled with the need to manage knowledge from different sources for successful service innovation, and also requires the capacity to sustain a constant flow of communication between the many agents (Green et al, 2013), which can be achieved through the establishment of routines and communication channels ${ }^{6}$. The important role of information technology in the communication and processing of information in the service innovation process is also emphasized (Di Meglio, 2013).

Thus, to analyze the participation as well as the role of civil society in public-private service innovation networks it is important to sustain an adequate standard of public services, taking into account the quality of service and social needs, particularly with regards to municipal solid waste services from the case of landfills with CDM projects.

In order to explore participation in the empirical context studied, as well as proposed by Labarthe et al (2013), the end-users are not individual users that are integrated within the networks. It is rather some collective organizations representing them (here representatives of associations from the communities surrounding landfills), which are members of the ServPPINs, as presented in the empirical results section.

\section{Empirical results: the Brazilian landfill CDM projects}

Of the 331 Brazilian CDM projects registered, 51 are developed on landfills, 23 of which are located in the State of São Paulo (UnepRisoe, December 2014). Our research focuses on the São Paulo Metropolitan Area, which is one of the five largest urban conurbations in the world, and the largest in Brazil, with the city of São Paulo as the main nucleus. It comprises 39 municipalities with, approximately, 20 million inhabitants, $55.4 \%$ in the city (municipality) of São Paulo.

The landfills for the empirical research were selected on the basis of the following criteria: a) carbon market Brazilian projects: regulated and voluntary carbon market; b) projects scope: landfill projects; c) Localization: São Paulo Metropolitan Area; d) Methodology used to measure GHG emission reduction: ACM0001 - flaring or use of landfill gas; e) Monitoring period verified: with at least one monitoring period verified until the beginning of the empirical research (February, 2014). Through the prior criteria mentioned, the landfills selected are: Bandeirantes, São João, Caieiras, Itapevi, Pedreira, and Lara.

The data on the CDM landfill projects, from 2003 to 2014, were obtained through documentary research in three databases: United Nations Environment Program (UNEPRisoe), and UNFCCC CDM Registry, for accessing monitoring reports and project design documents; and The Ministry of Science, Technology and Innovation (Ministério da Ciência e Tecnologia e Inovação- MCTI) database for accessing the project documentation, based on Annex III of Resolution No. 01/ 2003 of the Inter-ministerial Commission on Climate Change (CIMGC) (document that describes the promotion of social and environmental co-benefits).

Particularly for the analysis of the participation of associations, representatives of associations from the communities surrounding landfills, and recycling cooperatives, data were collected through semi-structured interviews organised into three categories to discuss opportunities for service innovations: consultation, benefits, and interface/interaction (Table 1).

\footnotetext{
${ }^{6}$ In the majority of ServPPINs cases analyzed by Djellal and Gallouj (2013) it is clear that organizational innovations are related to better sharing of information, establishment of communication channels, etc. Exemples: Capacity Planning (UK) in the health sector; ITS Vienna Region (AT1), DoRIS (AT3), VIATIC (FR1), and Compano (AT2) - in the transport sector.
} 


\begin{tabular}{ll}
\hline Category & Items Addressed \\
\hline Consultation & $\begin{array}{l}\text { Participation before and after project implementation; public consultation (public audiences, surveys, } \\
\text { questionnaires, workshops, visitation, panels); PDD comments; language and clarity of documents; } \\
\text { language used; community engagement }\end{array}$ \\
Benefits & $\begin{array}{l}\text { Cooperatives benefiting from CDM revenues; contributions of CDM projects to environmental } \\
\text { education programs }\end{array}$ \\
$\begin{array}{l}\text { Interaction/ } \\
\text { Interface }\end{array}$ & $\begin{array}{l}\text { Proposed meetings; disclosure of the annex III activities to stakeholders; channels for recording } \\
\text { complaints; the coordination role achieved by the public sector }\end{array}$ \\
\hline
\end{tabular}

Source: The authors

The interviews were conducted, in the first semester of 2014, with 4 associations and 3 waste-picker cooperatives engaged in the solid waste issue.

\subsection{Stakeholders Participation under the Carbon Market Projects}

With regards to participation, specifically for carbon market projects, the CDM Executive Board requires stakeholders' participation in the whole process of the activity development, fulfilling: 1) Project proponents should send letters of invitation to all project stakeholders; 2) Summary of information should be presented by the stakeholders; 3) Confirmation by the host country that the project assists in the achievement of sustainable development; 4) Report made of DNA justifying how the comments provided were taken into account.

The project information must be available in an appropriate manner, ensuring data accessibility, in a language and framework that can be understood by all stakeholders.

Even though stakeholder participation is explicitly considered by the CDM Executive Board, the process is still considered insufficient, in terms of contemplation of the actors, and in terms of measuring participation throughout the project cycle.

The participation of stakeholders in CDM projects has been widely challenged at the international level also (CAN, 2011; CDM Watch, 2010; Foronda et al., 2010; Subbarao and Lloyd, 2011; Kolmuss, 2012) indicating that there is still a gulf to be breached, due to the intense asymmetrical information among stakeholders and the lack of a clear understanding about how the resources from the sale of Certified Emission Reductions (CERs) should be applied, added to the unpreparedness of public bodies to clarify questions regarding the carbon market. Table 2 shows some elements related to public consultation, openness and transparency of information to support improvements in the participation of stakeholders.

Tab. 2 - Elements for stakeholder participation in carbon market projects

\begin{tabular}{lll} 
Topic & Public Consultation & $\begin{array}{l}\text { Openness and transparency of } \\
\text { information }\end{array}$ \\
\hline & $\begin{array}{l}\text { Quality and range of communication tools between the project } \\
\text { proponent and stakeholders (public audiences, surveys, questionnaires, }\end{array}$ & $\begin{array}{l}\text { Anticipation in the disclosure; } \\
\text { means of divulgation; } \\
\text { Elements }\end{array}$ \\
$\begin{array}{l}\text { workshops, visitors, panels, among other); Quality and range of } \\
\text { publicity needed to achieve stakeholders; Frequency and timing; Period }\end{array}$ & $\begin{array}{l}\text { accessibility of language and } \\
\text { language used }\end{array}$ \\
\end{tabular}
Source: based on Monzoni (2004) and CDM Watch ${ }^{7}$ (2010).

In 2011, through public consultation, the United Nations Framework Convention on Climate Change (UNFCCC) conducted a study aiming to contribute towards the inclusion of different actors in CDM projects. The key findings of the public consultation were:

- The comments of the stakeholders should be considered during the design of the project;

- The first meeting with the stakeholders should be taken prior to the submission of the PDD;

- Validation and verification of the project to ensure the required benefits; and

- The establishments of mechanisms for affected stakeholders to express their demands.

The elements outlined may contribute towards the fulfillment of the requirements related to the complete and effective involvement of communities surrounding landfills (and other stakeholders) on the project, through access to information and participation in the decision making process.

According to Decision 3/CMP.1 (Marrakech accords), UNFCCC defines stakeholders as: "the public, or any

\footnotetext{
${ }^{7}$ The CDM Watch is an organization created in 2009 with the purpose of supervising the actions performed under the CDM, particularly aimed at strengthening civil society participation processes.
} 
individuals, groups or communities affected or likely to be affected, by the proposed CDM project activities". Therefore the Designated Operational Entity (EOD), independent audit, responsible for the validation and verification of projects, should revise the PDD and other relevant documents for the validation and verification of the project, in order to evaluate, beyond the technical issues, if the requirements outlined by the CDM executive board in relation to stakeholders' participation ${ }^{8}$ are being met.

\subsection{Characterization of the landfills and identification of stakeholder}

The characterization of the landfills selected for the empirical research is shown Table 3.

Tab. 3 - Characterization of the landfills related to operation and CDM project

\begin{tabular}{|c|c|c|c|c|c|c|c|c|c|}
\hline Landfill & $\begin{array}{l}\text { Locatic } \\
\text { (São P } \\
\text { Metrop }\end{array}$ & $\begin{array}{l}\text { ulo } \\
\text { litan Area) }\end{array}$ & $\begin{array}{l}\text { Year of } \\
\text { beginning } \\
\text { landfill } \\
\text { operation / } \\
\text { closure }\end{array}$ & $\begin{array}{l}\text { Landfill } \\
\text { area } \\
(\text { ha) }\end{array}$ & $\begin{array}{l}\text { Public / } \\
\text { Private } \\
\text { landfill }\end{array}$ & $\begin{array}{l}\text { Tons of } \\
\text { waste / } \\
\text { day }\end{array}$ & $\begin{array}{l}\text { Project } \\
\text { registration } \\
\text { date on CDM } \\
\text { Registry }\end{array}$ & $\begin{array}{l}\text { Crediting } \\
\text { period }\end{array}$ & $\begin{array}{l}\text { Average } \\
\mathrm{tCO}_{2} \mathrm{el} \\
\text { year* }\end{array}$ \\
\hline Bandeirantes & $\begin{array}{l}\text { São } \\
\text { Paulo }\end{array}$ & $\begin{array}{l}\text { District of } \\
\text { Perus/ Zona } \\
\text { Oeste }\end{array}$ & $1979 / 2007$ & 140 & Public & 5,000 & 20 Feb 06 & $\begin{array}{l}\text { 1st: Sep } \\
06 \text { - Sep } \\
\text { 13/ } \\
\text { 2nd: Dec } \\
10-\text { Dec } \\
17\end{array}$ & $1,000,000$ \\
\hline São João & $\begin{array}{l}\text { São } \\
\text { Paulo }\end{array}$ & $\begin{array}{l}\text { District of } \\
\text { São Mateus/ } \\
\text { Zona Leste }\end{array}$ & $1992 / 2009$ & 84 & Public & 6,000 & 02 Jul 06 & $\begin{array}{l}\text { May } 07 \text { - } \\
\text { May } 14\end{array}$ & 800,000 \\
\hline Pedreira & $\begin{array}{l}\text { São } \\
\text { Paulo }\end{array}$ & $\begin{array}{l}\text { District of } \\
\text { Tremembé/ } \\
\text { Zona Norte }\end{array}$ & 2001 & 56,2 & Private & 1,200 & 12 Feb 08 & $\begin{array}{l}\text { Feb 08- } \\
\text { Feb } 15\end{array}$ & 185,000 \\
\hline Caieiras & \multicolumn{2}{|c|}{ Caieiras } & 2002 & 350 & Private & 7,000 & 09 Mar 06 & $\begin{array}{l}\text { Mar } 06 \text { - } \\
\text { Mar } 13\end{array}$ & 770,000 \\
\hline Itapevi & \multicolumn{2}{|l|}{ Itapevi } & 2003 & 20,5 & Private & 900 & 17 Aug 07 & $\begin{array}{l}\text { Aug } 07 \text { - } \\
\text { Aug } 14\end{array}$ & 90,000 \\
\hline Lara & Mauá & & 1987 & 30 & Private & 1,500 & 15 May 06 & $\begin{array}{l}\text { 1st: Sep } \\
06 \text { - Sep } \\
\text { 13/ } \\
\text { 2nd: Dec } \\
10 \text { - Dec } \\
17\end{array}$ & 750,000 \\
\hline
\end{tabular}

* These data are based on the preliminary modelled/projected emission reductions from the PDD

The PDD section named "Stakeholders consultation"" was investigated for each landfill selected as an empirical case, in order to map the stakeholders. A weakness was verified in the PDD, particularly in relation to the actors considered as "potentially affected populations", i.e, communities surrounding landfills.

In the PDD "Stakeholders consultation" section, the stakeholders representative of civil society largely cited was the Brazilian Forum of NGOs and Social Movements for the Environment and Development; in other words, although the Forum is widely recognized for actions and activities aimed at protecting the environment and promoting sustainable development, it is generally for the purpose of this research to consider it as a stakeholder.

Thus, specific information about representatives of associations from the communities surrounding landfills

\footnotetext{
${ }^{8}$ The requirements are: Project proponents should send letters of invitation to all project stakeholders; Summary of information presented by the stakeholders; Confirmation by the host country that the project assists in the achievement of sustainable development; Report of DNA justifying how the comments provided were taken into account.

${ }^{9}$ This section includes: A brief description of how comments by local stakeholders have been invited and compiled; a summary of the comments received; and a report on how due account was taken of any comments received.
} 
directly affected by the activities of the enterprises was researched beyond the project design documents and the UNFCCC website, as well as direct searches on Google being used (web search engine tool) with the keywords: landfills name; cooperatives; associations/communities surrounding landfills.

In addition, the following databases were checked:

$\checkmark$ Recyclable material Cooperatives listing, available in the website Department of Environment of São Paulo State - SMA ${ }^{10}$;

$\checkmark$ "Registration of civil society organizations - database of 2009-2011" listing, available in the integrated Water Resources Management System (SIGERH) ${ }^{11}$, taking into account mainly the data related to the watershed committee of Alto Tietê, regarding the geographical area selected for study;

$\checkmark$ Websites of the municipalities at Itapevi, Mauá, and Caieiras;

$\checkmark$ Websites of the subdistricts São Mateus, Perus, and Tremembé (city of São Paulo);

$\checkmark$ Minutes of public audiences related to carbon credits;

$\checkmark$ FEMA (Environment and Sustainable Development Fund) and Confema (Special Fund for the Environment and Sustainable Development Council) resolutions related to CDM projects (in this case, only for Bandeirantes and São João CDM projects).

Figure 1 shows, specifically, the stakeholders' mapping of the representatives of associations from the communities surrounding landfills.

[Figure-1]

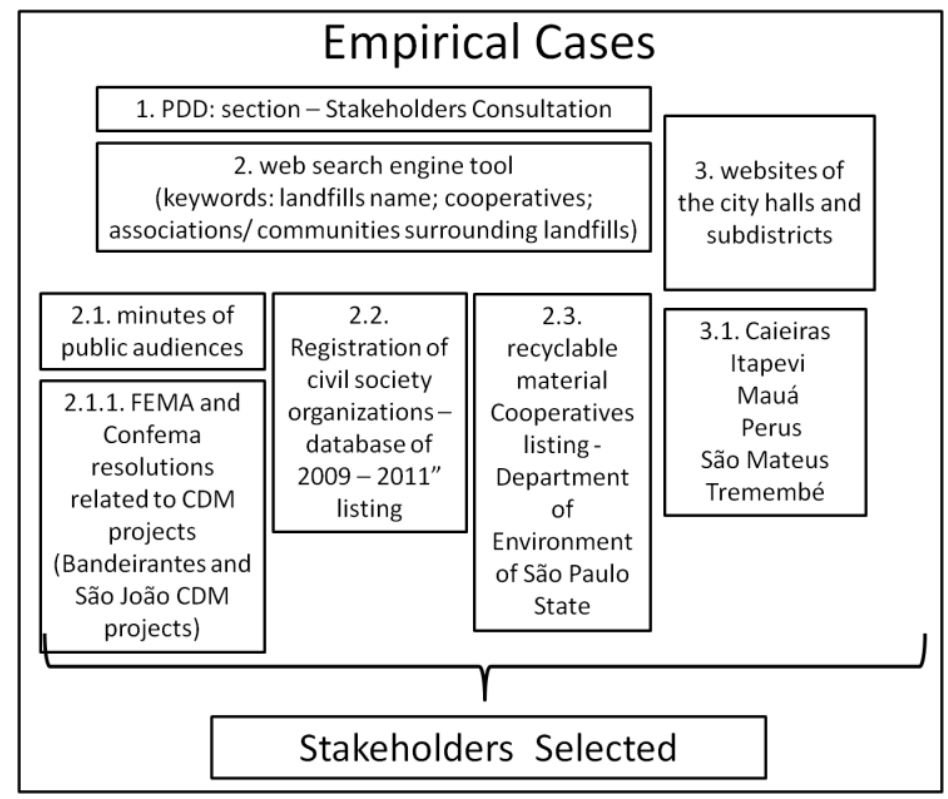

Fig. 1 - Stakeholders' Mapping - associations from the communities surrounding landfills Source: The authors.

From this mapping (addressed previously in Fig. 1), Table 4 shows the representatives of associations selected.

Tab. 4 - Representatives of associations selected

\begin{tabular}{|c|c|c|}
\hline Landfill & Representatives of Associations & Description \\
\hline Bandeirantes & $\begin{array}{l}\text { Perus and Anhanguera Forum for } \\
\text { local sustainable development }\end{array}$ & $\begin{array}{l}\text { Founded in } 2003 \text { with the purpose of organizing the popular } \\
\text { participation and demand improvements for the region of Perus. }\end{array}$ \\
\hline & Chico Mendes Cooperative & $\begin{array}{l}\text { Founded in } 1999 \text { with the purpose employment generation for } \\
\text { people on low income in the East Zone of São Paulo }\end{array}$ \\
\hline São João & $\begin{array}{l}\text { More Life, Less Rubbish } \\
\text { Campaign (Campanha Mais Vida } \\
\text { Menos Lixo) }\end{array}$ & $\begin{array}{l}\text { Initiative of the residents of São Matheus district that have } \\
\text { mobilized against the bad odours and the possibility of accidents } \\
\text { occurring due to the activities performed by the landfill }\end{array}$ \\
\hline Caieiras & $\begin{array}{l}\text { Pinheiros Philanthropic } \\
\text { Association }\end{array}$ & $\begin{array}{l}\text { Founded in } 1993 \text { with the purpose to assist the local residents of } \\
\text { Caieiras region (around } 450 \text { families) }\end{array}$ \\
\hline
\end{tabular}




\begin{tabular}{|c|c|c|}
\hline Pedreira & Cantareira Viva Cooperative & $\begin{array}{l}\text { Founded in } 2006 \text { with the purpose to enable the selective waste } \\
\text { collection, income generation, and stimulate improvements in Vila } \\
\text { Albertina the region (a neighborhood in the Jaçanã/Tremembé } \\
\text { district, São Paulo) }\end{array}$ \\
\hline Itapevi & Itapevi Cooperative & $\begin{array}{l}\text { Founded in } 2003 \text { supported by the Municipal Department of } \\
\text { Environment. Currently with } 20 \text { registered cooperative members }\end{array}$ \\
\hline Lara & $\begin{array}{l}\text { Association of Literacy Movement } \\
\text { for Youth and Adults (AMOVA) }\end{array}$ & $\begin{array}{l}\text { Founded in } 2002 \text { in the city of Mauá; is focused on providing } \\
\text { housing to low income people, through partnerships with Caixa } \\
\text { Economica Federal (Brazilian bank) and the Ministry of Cities }\end{array}$ \\
\hline
\end{tabular}

For the public sector, stakeholders include the city halls and municipal sub districts, as well as the departments related to CDM projects issues. For the private sector, the stakeholders include the concessionholders responsible for landfill management in the case of public landfills, the company that owns the landfills in the case of private landfills; and the concession-holders responsible for biogas recovery and power generation.

\subsection{Participation Gaps}

The role and participation that civil society has to play in the ServPPIN - helping to translate social preferences - are fundamental to promote service innovation. Besides that, within the CDM projects context, participation is considered a core issue for the project to comply with the goal of promoting local sustainable development.

According to data collected from the representatives of civil society, the communities surrounding landfills lack information regarding the existence and operation of the CDM landfill projects; in addition there is no knowledge about local benefits promotion that the projects must perform. The major gaps identified are addressed in the following topic.

\section{a) Consultation}

The period designated for stakeholders to manifest their opinion about the project (30 days, set by UNFCCC) is considered inappropriate by the interviewees' representatives of Bandeirantes, São João, and Itapevi landfills. The interviewees of the other landfills were unaware about the availability of documents related to the CDM projects to be accessed and commented on.

Other issues raised are related to: difficulties in obtaining documents in the UNFCCC and MCT\&I online platforms; the lack of documents available in the native language; and the technical language used in the documents related to the projects. Without a common language, surrounding communities may remain unaware of any possible benefits arising out of project implementation. Furthermore, the establishment of a common language can improve exposure of the different interests at stake. The asymmetric information problem diminishes, or even hampers, an effective participation of the associations of residents surrounding landfills.

With the exception of the Bandeirantes and São João landfills, which both held public audiences and meetings, there is no information on the existence of meetings, workshops and other types of mechanisms to facilitate the participation at the other landfill sites. However, even in the Bandeirantes and São João landfills cases, it is emphasized that the respective communities suffer difficulties to voice their claims in an effective manner: The views of the municipality and the operating company's technicians usually prevail.

It is thus necessary to develop the competence of the associations (from the communities surrounding the landfills) to discuss technical indicators about landfill operation and closure plans, as well as other alternatives for final waste disposal. There is a need on the part of technicians at the municipal departments, concessionholders, and CDM project developers to ensure that data communicated about CDM projects can be easily understood by the communities surrounding the landfills.

With regards to the PDD section named "Stakeholder consultation", only the Bandeirantes landfill did not receive comments from stakeholders. For other landfills, the comments were generally performed by Municipal Departments of Environment, Public prosecution, and state and municipal environmental bodies.

Only the Itapevi landfill received comments from the Brazilian Forum of NGOs, pointing out the need for improvements in local stakeholder involvement and the importance of setting up transparency mechanisms related to the projects; and Itapevi Public Prosecution declaring that the PDD of the landfill was not submitted in a local consultation process. Therefore, it is observed that the comments received mostly do not regard the stakeholders as set out by the Kyoto Protocol: Individuals, groups or communities affected or likely to be affected, by the proposed CDM project activities. 


\section{b) Benefits}

According to the preferences of representatives of civil society, the projects should contribute to reduce or to avoid negative externalities generated by landfills. That is, to reduce pollution; to reduce risks (related to the activities performed by landfills); to increase quality of life; to ensure cooperatives and environmental education programs benefit from the resources of CDM.

In the PDDs, only Caieiras and Lara landfills mentioned the proposition of future projects to be carried out from the CER resources. Despite this, the absence of means for monitoring/supervising, if these proposals are to be implemented, is brought to attention.

The cooperative of Itapevi, was awarded with equipment for compacting waste; and the Caieiras landfill transfers $1 \%$ of the CER resources (Candiani et al 2013) to the Municipal Social Fund to be invested in the areas of education, health and environment. For the other landfills, there is no information about cooperatives and associations that benefited with the resources of the projects.

Specifically for Bandeirantes and São João landfills, problems of access to revenue from the sale of Certified Emission Reductions are noteworthy. The access to CER resources intended for FEMA ${ }^{12}$ occurs through public tenders. However, sub-districts need to develop their competence in order to be able to publicize good quality projects and thus access revenue from the sale of carbon credits.

ServPPINs require increased flexibility from the public sector. Therefore, particularly in relation to the means for accessing the resources from CER (public tenders), it is recommendable to review the public tenders, adapting the requirements to the real situation of the cooperatives; to propose ways to support the cooperatives (i.e. action plans to capacitate the cooperatives to be able to design good quality projects and thus access the revenues from the sale of carbon credits); to prevent that bureaucratic issues hinder access to CER resources.

\section{c) Interaction/Interface}

While evaluating the existence of communication channels for receiving complaints, inquiries and comments from stakeholders, it is pointed out that there are no effective channels for participation of civil society associations and cooperatives surrounding landfills throughout the stages of the project cycle. Some of the complaints mentioned by the interviewees affected by the São João, Bandeirantes, Itapevi, and Caieiras landfills are related mainly to: the odor from the landfills; the misdirection of the resources derived from the sale of CERs; and the lack of benefits generated from the projects for the community. Moreover, it is observed that there is a need to publicize activities related to CDM projects and implement an effective communication channel that would improve discussions, negotiations and disclosure to the various stakeholders via public consultations and dialogue mechanisms.

Largely, the interactions are restricted to public audiences and meetings concerning the application of the resources from the sale of the carbon credits generated by Bandeirantes and São João CDM projects. At the other landfills, the interface is considered only by the availability of documents in the UNFCCC and MCT\&I online platforms to receive stakeholders' comments about the projects. As highlighted by the ServPPIN concept, it is essential to empower the public sector and civil society for cooperation. In addition, it is important for the public sector to perform network coordination in an appropriate manner.

\section{Conclusion}

The ServPPIN concept highlights the importance of interaction/interface among public and private organizations and mainly, third sector organizations, for developing innovative services.

In this way, through the application of the ServPPIN concept, it was possible to identify and analyze the factors related to the establishment of fundamental conditions for public service innovation in the municipal solid waste sector through the implementation of landfill CDM projects.

For the analysis, the following variables were considered: consultation; benefits; interaction/interface.

$\checkmark$ Regarding consultation, the main gaps identified are related to the period for stakeholders to voice their opinion about the project - 30 days, as set out by UNFCCC, is considered inappropriate. Other issues raised are related to: difficulties in obtaining documents in the UNFCCC and MCT\&I online platforms; the lack of documents available in the native language; and the technical language used in the documents related to the projects (generating asymmetric information). The comments pointed out in PDD section "Stakeholder consultation" in general, do not regard the stakeholders as set out by the Kyoto Protocol (individuals, groups or communities affected or likely to be affected, by the proposed CDM

\footnotetext{
${ }^{12} 50 \%$ of the revenues from the Certified Emissions Reductions (CER) of the Bandeirantes and São João landfills are allocated to municipal government, specifically to the Environment and Sustainable Development Fund - FEMA, which is administered by the Municipal Department for the Environment.
} 
project activities).

$\checkmark$ Regarding the benefits provided by project implementation, the absence of means for monitoring/supervising is highlighted, if the proposals described in the documents related to the projects are to be implemented. Additionally, and specifically for Bandeirantes and São João landfills, problems are noteworthy of access to revenue from the sale of Certified Emission Reductions, which occurs through public tenders, and the need to develop competences is highlighted, in order to make the cooperatives able to design good quality projects and, thus, access the revenue from the sale of carbon credits.

$\checkmark$ Regarding the interaction/interface, the absence of effective channels for receiving complaints, inquiries and comments from stakeholders and the need to publicize activities related to CDM projects throughout the whole crediting period are noteworthy. For the Bandeirantes and São João landfills, interactions are restricted to public audiences and meetings concerning the application of resources from the sale of carbon credits. For the other landfills, interface is only considered from the availability of the documents in the UNFCCC and MCT\&I online platforms.

Overall, the results presented corroborate with the results shown in the international literature regarding stakeholder participation under the carbon market projects (CAN, 2011; CDM Watch, 2010; Foronda et al., 2010; Subbarao and Lloyd, 2011; Kolmuss, 2012), and in the ServPPIN research Project results (Gallouj et al, 2013) pointing out that service end user (citizen) involvement is marginal.

ServPPINs enable potential complementarities and synergies to be explored in various modes of cooperation between public, private and civil society organizations. In this way, in the instances studied, it is essential to empower the public and private sectors and civil society. Besides this, it is important the public sector performs the coordination of the network in an appropriate way. The proactive role of the public sector as a network leader turns out to be a very important determinant of success in the CDM landfills cases, as instruments capable of contributing to public service innovation in the municipal solid waste sector.

Pulling this theoretical (ServPPIN) and empirical research (landfill CDM project) together, once can identify the main factors constraining and affecting the establishment of the basic conditions for service innovation. Based on the set of case-studies investigated, lessons have been drawn concerning:

a) The interactions and the building of social relations aimed at innovation among various stakeholders involved;

b) The development of competence on several fronts, especially, relational and organizational; and

c) The role of the public sector (mainly, the coordination role) in supporting the development of successful public-private innovation networks in services.

\section{References}

Bloch, C.; Bugge, M. 2013. Public sector innovation - From theory to measurement, Journal Structural Change and Economic Dynamics. DOI: 10.1016/j.strueco.2013.06.008

Brandão; S. M.; Bruno-Faria, M. F. 2013. Inovação no setor público: análise da produção científica em periódicos nacionais e internacionais da área de administração, Rev. Adm. Pública — Rio de Janeiro 47(1):227-248, jan./fev. DOI: 10.1590/s0034-76122013000100010.

Brazil, 2010. Lei $n^{\circ}$ 12.305, Política Nacional de Resíduos Sólidos, de 2 de agosto de 2010

Brazil, 2003. Comissão Interministerial de Mudanças Globais do Clima - CIMGC, Resolução n.1 de 11 de setembro de 2003.

Brazil, 1997. Protocolo de Kyoto à Convenção sobre Mudança do Clima, 1997. Editado e traduzido pelo Ministério da Ciência e Tecnologia - MCT com o apoio do Ministério das Relações Exteriores. Available from: < http://www.mct.gov.br/upd_blob/0012/12425.pdf >. (Retrieved: 04.02.13).

Bučar, M., Stare, M., Jaklič, A., 2013. Weak institutional framework as incentive for service innovation networks: focus on knowledge-intensive business services, In Public-Private Innovation Networks in Services: the dynamics of cooperation in service innovation, Edward Elgar publishers.

Bugge, M., Hauknes, J., Bloch, C. and Slipersæter, S., 2010. The public sector in innovation systems, Project - Measuring Public Innovation in the Nordic Countries: Toward a common statistical approach.

CAN - Climate Action Network, 2011. CDM Executive Board call for Inputs on the Validation Process. Climate Action Network International.

Candiani, G.; Cortez, A. C. 2013. Análise Da Implantação Das Medidas Mitigadoras Estabelecidas No Estudo De Impacto Ambiental Da Central De Tratamento De Resíduos - Caieiras - São Paulo, Bol. geogr., Maringá, v. 31, n. 2, p. 115-130, maio.-ago. DOI: 10.4025/bolgeogr.v31i2.13419. 
CDM WATCH, 2010. Manual para o Mecanismo de Desenvolvimento Limpo (MDL). CDM Watch Tool Kit. Available from <www.carbonmarketwatch.org> (retrieved 08.10. 2013).

Cetesb, 2013. Inventário Estadual de Resíduos Sólidos Urbanos. Available from<http://www.cetesb.sp.gov.br/userfiles/file/residuos-solidos/residuosSolidos2013.pdf> (retrieved 08.10. 13).

Di Meglio, G., 2013. The place of ServPPINs in the range of public-private collaboration arrangements for services provision, In Public-Private Innovation Networks in Services: the dynamics of cooperation in service innovation, Edward Elgar publishers. DOI: 10.4337/9781781002667.00009.

Djellal, F., Gallouj, F., 2012. Beyond Productivity Measurement and Strategies: Performance Evaluation and Strategies in Services, Working Papers halshs-00748099, HAL. DOI: 10.3917/jie.005.0089.

Djellal F., Gallouj, F., Miles, I. 2013. Two decades of research on innovation in services: which place for public services?, Structural Change and Economic Dynamics. DOI: 10.1016/j.strueco.2013.06.005.

Djellal F., Gallouj, F., 2013. How Public-Private Innovation Networks in Services (ServPPINs) differ to other innovation networks: What lessons for theory? In Gallouj F., Rubalcaba L., Windrum P. (eds), Public-Private Innovation Networks in Services: the dynamics of cooperation in service innovation, Edward Elgar publishers. DOI: $10.4337 / 9781781002667.00008$.

Farias, J.; Almeida, J. 2014. Technology adoption in service organizations: a framework proposal for studying ICT diffusion in healthcare and hospital services. Services and New Societal Challenges: Innovation for Sustainable Growth and Welfare - XXIV International Conference of RESER, September 11-13 2014, Helsinki, Finland.

Foronda, C.; Cordova, M. M. M.; Gárate, I. O.; Pacora, C.; Rengifo, M. Q.; López, C. N. 2010. Análisis y mejora de la participación de comunidades locales em proyectos de mercado de carbono. Fundación MAPFRE.

Fuglsang, L., 2010. Bricolage and invisible innovation in public service innovation, Journal of Innovation Economics, vol 1, no. 5, pp. 67-87. DOI: 10.3917/jie.005.0067.

Fuglsang, L., 2013. Collaboration and trust in a public-private innovation network: a case study of an emerging innovation model. In Public-Private Innovation Networks in Services: the dynamics of cooperation in service innovation, Edward Elgar publishers. DOI: 10.4337/9781781002667.00018.

Gallouj, F; Weinstein, O., 1997. Innovation in Services. Research Policy, v.26, p.537-556. DOI: 10.1016/s00487333(97)00030-9

Gallouj F., Rubalcaba L., Windrum P. 2013. Public Private Innovation Networks in Services, Edward Elgar Publishers. DOI: 10.4337/9781781002667.00006.

Green, L.; Pyka, A.; Schön, B., 2013. A life cycle-based taxonomy of innovation networks - with a focus on public-private collaboration. In Gallouj F., Rubalcaba L., Windrum P. (eds), Public-Private Innovation Networks in Services: the dynamics of cooperation in service innovation, Edward Elgar publishers. DOI: 10.4337/9781781002667.00011.

Hartley, J., 2005. Innovation in Governance and Public Services: Past and Present, Public money \& management, January. DOI: 10.1080/09540962.2011.598298 .

Halvorsen, T., Hauknes, J., Miles, I. , Røste, R., 2005. On the differences between public and private sector innovation. Oslo: PUBLIN. DOI: 10.1201/b17194-3

Hertog, P. en, Van Der, W. \& de Jong, M.W, 2010. Capabilities for managing service innovation: towards a conceptual framework, Journal of Service Management vol. 21 no. 4 pp. 490-514. DOI: 10.1108/09564231011066123.

Koch, P.; Hauknes, J., 2005. Innovation in the public sector. Report no D20. Publin project under the EU 5th Framework Programme. Oslo: NIFU STEP.

Kolmuss, A. 2012. Improving the Stakeholder Consultation Process: an NGO perspective. CDM Watch. CDM Roundtable.

Labarthe, P., Gallouj, F., Djellal, F., 2013. Effects of institutions on the integration of end-users' knowledge in ServPPINs: lessons from two case studies in agro-environmental knowledge-intensive services. In Gallouj F., Rubalcaba L., Windrum P. (eds), Public-Private Innovation Networks in Services: the dynamics of cooperation in service innovation, Edward Elgar publishers. DOI: 10.4337/9781781002667.00020.

Langergaard, L.; Scheuer, D. (2009) Specificities of public sector service innovation. ServPPIn Report D2.1. DOI: 10.1007/978-1-4614-1972-3_31

Lehtonen, M., Tuominen, T . 2013. Multiple Voices of the User in Public Sector Services. Elgar Online. Edward Elgar Publishing, Inc.. Cheltenham, UK. n.d. Web. 14 Nov. DOI: 10.4337/9780857931962.00020 .

Monzoni, M. 2004. Critérios de sustentabilidade para projetos MDL no Brasil. Colaboração Silvia Llosa. Instituto de Pesquisa Ambiental da Amazônia - IPAM. Brasil.

Mulgan, G.; Albury, D., 2003. Innovation in the Public Sector, Strategy Unit, London: Cabinet Office Strategy Unit, UK Cabinet Office, October. DOI: 10.1016/s1754-4548(09)70100-7

Osborne, S.P. Brown, L. 2013. Handbook of Innovation in Public Services. Cheltenham: Edward Elgar.

PORTAL IBGE CIDADES. Available from: 〈http://www.ibge.gov.br/cidadesat>. (retrieved 10.11. 13).

Potts J, Kastelle, T., 2010. Public sector innovation research: what's next? Innovation: Management, Policy \& Practice 12(2): 122-137.

Prefeitura do Município de Mauá, 2012. Plano Municipal de Resíduos Sólidos Mauá. Available from: <http://www.maua.sp.gov.br/> (retrieved 10.11.13).

Prefeitura Municipal de Caieiras, 2013. Primeira reunião para discutir o Plano Municipal de Saneamento Básico aconteceu na quarta-feira, notícia divulgada no portal online do município em 21 Novembro 2013. Available from: $<\mathrm{http} / / /$ www.caieiras.sp.gov.br/index.php/meio-ambiente/1332-primeira-reuniao-para-discutir-o-plano-municipal-desaneamento-basico-aconteceu-na-quarta-feira (retrieved 10.11. 13).

Prefeitura Municipal de Itapevi, 2012. Plano Municipal de Gestão Integrada de Resíduos Sólidos de Itapevi-SP (PGIRS), Secretaria Municipal Do Meio Ambiente. Available from:

<http://www.itapevi.sp.gov.br/noticiasNovo/sec_meio_ambiente/drs.php (retrieved 10.11.13). 
Prefeitura Municipal de Mauá, 2012. Plano Municipal de Resíduos Sólidos. Available from: <http://www.maua.sp.gov.br/ (retrieved 10.11.13).

Rede Nossa São Paulo, 2011. As Subprefeituras, os Distritos e o Município de São Paulo: Subprefeitura Perus, Subprefeitura São Mateus, Subprefeitura Jaçanã - Tremembé. Available from:

<http://www.nossasaopaulo.org.br/observatorio/regioes.php (retrieved 10.11. 13).

Schilling, A. 2011. Skills and competences supporting service innovation - a literature review, VINNOVA - Swedish Governmental Agency for Innovation Systems / Verket för Innovationssystem, ISBN: 978-91-86517-51-9.

Schartinger, D. (2013) An institutional analysis of innovation in healthcare services, In Gallouj F., Rubalcaba L., Windrum P. (eds), Public-Private Innovation Networks in Services: the dynamics of cooperation in service innovation, Edward Elgar publishers. DOI: 10.4337/9781781002667.00016.

Siebel, M.; Rotter, V.; Gupta, J. 2013. Clean Development Mechanism - A Way to Sustainable Waste Management in Developing Countries? Österreichische Wasser- und Abfallwirtschaft, , Volume 65, Issue 1-2, February 2013, pp 42-46. DOI: $10.1007 / \mathrm{s} 00506-012-0052-4$

Speer, J. 2012. Participatory Governance Reform: A Good Strategy for Increasing Government Responsiveness and Improving Public Services? World Development, Volume 40, Issue 12, December 2012, Pages 2379-2398, ISSN 0305750X. DOI: 10.1016/j.worlddev.2012.05.034 .

Subbarao, S.; Lloyd, B. 2011. Can the Clean Development Mechanism (CDM) deliver? Energy Policy, 39, 2011, p. 16001611. DOI: $10.1016 /$ j.enpol.2010.12.036

Sundbo, J. 2011. User-employee encounter based service innovation and blocking of innovation processes, ICE-Project Working Paper, ISSN: 1903-5349, 2011, Roskilde University/Center for Communication, Media and Information Technologies: Aalborg University, Denmark.

Sundbo, J.,2013. Public-private innovation networks in services: the crucial role of entrepreneurial fit. In Gallouj F., Rubalcaba L., Windrum P. (eds), Public-Private Innovation Networks in Services: the dynamics of cooperation in service innovation, Edward Elgar publishers. DOI: 10.4337/9781781002667.00022 .

Sutter, C., Parreño, J. 2007. Does the current CDM deliver its sustainable development claim? An analysis of officially registered CDM projects: Climatic Change, v. 84. DOI: 10.1007/s10584-007-9269-9

UNEP RISOe, 2014. United Nations Environment Programme. Capacity Development for the CDM, CDM projects in the pipeline Analysis and Database, December 2014. Available from: <//www.cd4cdm.org/> (retrieved 12.01.15).

UNFCCC, 2001. The Marrakesh Accords \& The Marrakesh Declaration, Conference of the Parties at its seventh session Available from: <http://unfccc.int/cop7/documents/accords_draft.pdf> (retrieved 12.06.13).

UNFCCC, 2005a.United Nations Framework Convention on Climate Change. Project Design Document: Bandeirantes Landfill Gas Project. Available from: <http://cdm.unfccc.int/>. (retrieved 09.09.12).

UNFCCC, 2005b. United Nations Framework Convention on Climate Change. CDM Executive Board. Project Design Document: São João Landfill Gas Project, Available from: <http://cdm.unfccc.int/>. (retrieved 09.09.12).

UNFCCC, 2013. Project Design Document: Caieiras landfill gas emission reduction, 2013. Available from: $<\mathrm{http} / / / \mathrm{cdm}$. unfecc.int/>. (retrieved 10.11. 13)

UNFCCC, 2007. Project Design Document: ESTRE Itapevi Landfill Gas Project (EILGP). Available from: $<$ http://cdm.unfccc.int/>. (retrieved 10.11.13)

UNFCCC, 2010. Project Design Document: ESTRE Pedreira Landfill Gás Project (EPLGP). Available from: $<$ http://cdm.unfecc.int/>. (retrieved 10.11.13)

UNFCCC, 2006. Project Design Document: Landfill Gas to Energy Project at Lara Landfill. Available from: $<\mathrm{http}: / / \mathrm{cdm}$.unfccc.int/>. (retrieved 10.11.13)

UNFCCC, 2011. Benefits to Clean Development Mechanism. Available from: < http://cdm.unfccc.int/about/dev_ben/ABC_2012.pdf >. (retrieved 10.11. 13)

Windrum, P., 2013. Innovation and entrepreneurship in public services. In Gallouj F., Rubalcaba L., Windrum P. (eds), Public-Private Innovation Networks in Services: the dynamics of cooperation in service innovation, Edward Elgar publishers. DOI: 10.4337/9781848441545.00009.

Windrum, P., Garcia-Goñi, M., 2008. A neo-Schumpeterian model of health services innovation, Research Policy, Elsevier, vol. 37(4), pages 649-672, May. DOI: 10.1016/j.respol.2007.12.011 